\title{
KETERKAITAN ANTARA JUMLAH UMKM DAN TINGKAT TEKNOLOGI TERHADAP PERTUMBUHAN EKONOMI DI JAWA TIMUR
}

\author{
Widhi Ariestianti Rochdianingrum \\ widhiariestianti@stiesia.ac.id \\ Teguh Gunawan Setyabudi \\ Sekolah Tinggi Ilmu Ekonomi (STIESIA) Surabaya
}

\begin{abstract}
The increase in output on economic activity is an important indicator for the economic development process in East Java Province. There are several important factors that influence economic growth in East Java Province including the number of micro, small and medium enterprises and the level of technology used. The purpose of this study was to determine the effect of the number of micro small and medium enterprises and the level of technology used on economic growth in the Province of East Java. The independent variable used is the number of micro small and medium enterprises and the level of technology used. The dependent variable used is economic growth. The analytical method used is multiple regression analysis. The results of the study show that there is a significant relationship between the number of micro, small and medium enterprises and the level of technology used in the economic growth of East Java Province. The large number of micro, small and medium enterprises, this will have an impact on the higher economic growth. The higher level of technology used, it will also have an impact on the higher economic growth.
\end{abstract}

Key words: economic growth; level of technology; the number of micro small and medium enterprises.

\begin{abstract}
ABSTRAK
Adanya peningkatan atas output yang dihasilkan dalam kegiatan ekonomi merupakan suatu indikator yang penting bagi proses pembangunan ekonomi di Provinsi Jawa Timur. Terdapat beberapa faktor penting yang mempengaruhi pertumbuhan ekonomi di Provinsi Jawa Timur diantaranya jumlah usaha mikro kecil menengah dan tingkat teknologi yang digunakan. Tujuan penelitian ini untuk mengetahui pengaruh jumlah usaha mikro kecil menengah dan tingkat teknologi yang digunakan terhadap pertumbuhan ekonomi di Provinsi Jawa Timur. Variabel independen yang digunakan adalah jumlah usaha mikro kecil menengah dan tingkat teknologi yang digunakan. Variabel dependen yang digunakan adalah pertumbuhan ekonomi. Metode analisis yang digunakan adalah analisis regresi berganda. Berdasarkan hasil analisis didapatkan bahwa terdapat hubungan yang signifikan antara jumlah usaha mikro kecil menengah dan tingkat teknologi yang digunakan terhadap pertumbuhan ekonomi Provinsi Jawa Timur. Semakin banyak jumlah usaha mikro kecil menengah yang ada maka semakin tinggi tingkat pertumbuhan ekonomi. Semakin tinggi tingkat teknologi yang digunakan maka pertumbuhan ekonomi akan semakin tinggi.
\end{abstract}

Kata kunci: pertumbuhan ekonomi; tingkat teknologi; jumlah usaha mikro kecil dan menengah.

\section{PENDAHULUAN}

Pertumbuhan ekonomi merupakan salah satu faktor yang penting bagi suatu daerah. Pertumbuhan ekonomi merupakan salah satu indikator keberhasilan pembangunan ekonomi. Suatu wilayah atau daerah yang mempunyai pertumbuhan ekonomi yang bagus merupakan suatu daya tarik tersendiri bagi masyarakat. Suatu wilayah dikatakan memiliki pertumbuhan ekonomi yang baik jika terdapat pertambahan out put yang dihasilkan oleh kegiatan ekonomi wilayah tersebut setiap tahunnya. Pertumbuhan ekonomi suatu wilayah me- 
miliki hubungan yang erat dengan pembangunan ekonomi. Pembangunan ekonomi merupakan proses perubahan yang terjadi secara terus menerus pada struktur produksi serta alokasi penggunaan input pada berbagai sektor ekonomi. Pembangunan ekonomi yang baik dapat mendorong terjadinya pertumbuhan ekonomi, pertumbuhan ekonomi yang bagus dapat memperlancar pembangunan ekonomi, sehingga dapat dikatakan bahwa pertumbuhan ekonomi dan pembangunan ekonomi memiliki hubungan yang saling bergantung satu sama lain. Pembangunan ekonomi pada suatu wilayah merupakan suatu proses perpaduan antara pertambahan penduduk dengan kemajuan teknologi yang ada di wilayah tersebut.

Pada provinsi Jawa Timur sendiri secara global dapat dikatakan memiliki pembangunan ekonomi yang baik. Hal ini dapat terlihat dari besarnya pertumbuhan ekonomi yang dimiliki oleh provinsi Jawa Timur. Pertumbuhan ekonomi di provinsi Jawa Timur dapat dilihat dari besarnya nilai produk domestik regional bruto (PDRB) berdasarkan harga konstan.

Produk domestik regional bruto berdasarkan harga konstan menunjukkan kenaikan out put yang dihasilan oleh provinsi Jawa Timur setiap tahunnya tanpa dipengaruhi oleh faktor kenaikan harga yang terjadi setiap tahunnya (inflasi). Besarnya pertumbuhan ekonomi di provinsi Jawa Timur dapat dilihat pada Tabel 1 dibawah ini.

Tabel 1

Pertumbuhan Ekonomi Provinsi Jawa Timur 2011 - 2016

\begin{tabular}{cr}
\hline Tahun & \multicolumn{1}{c}{ PDRB } \\
\hline 2010 & 342.281 .000 .000 .000 \\
2011 & 366.983 .000 .000 .000 \\
2012 & 393.663 .000 .000 .000 \\
2013 & 419.428 .000 .000 .000 \\
2014 & 1.262 .684 .500 .000 .000 \\
2015 & 1.331 .395 .000 .000 .000 \\
2016 & 1.405 .236 .100 .000 .000 \\
\hline
\end{tabular}

Sumber : BPS Jawa Timur 2010 - 2016
Berdasarkan Tabel 1 pada tahun 2010 sampai dengan tahun 2016 di provinsi Jawa Timur pertumbuhan ekonomi cenderung mengalami peningkatan. Pada tahun 2010 sampai tahun 2011 provinsi Jawa Timur memiliki pertumbuhan ekonomi sebesar Rp 24.702.000.000.000. Pada tahun 2011 sampai 2012 di provinsi Jawa Timur terdapat peningkatan pertumbuhan ekonomi sebesar Rp 26.650.000.000.000. Pada tahun 2012 sampai tahun 2013 di provinsi Jawa Timur terdapat peningkatan pertumbuhan ekonomi sebesar Rp 25.765.000.000.000. Pada tahun 2013 sampai 2014 terdapat peningkatan pertumbuhan ekonomi sebesar Rp 843.256.500.000.000. Pada tahun 2014 sampai 2015 di provinsi Jawa Timur terdapat pertumbuhan ekonomi sebesar $\mathrm{Rp} 68.710$. 500.000.000. Pada tahun 2015 sampai 2016 di provinsi Jawa Timur terdapat peningkatan pertumbuhan ekonomi sebesar Rp 73.841. 100.000.000. Berdasarkan penjelasan diatas dapat diketahui bahwa pertumbuhan ekonomi yang cukup signifikan terjadi antara tahun 2013 sampai tahun 2014. Pada tahun tahun yang lain pertumbuhan ekonomi di provinsi Jawa Timur memiliki pertumbuhan ekonomi dengan kenaikan yang tidak signifikan.

Besarnya pertumbuhan ekonomi di provinsi Jawa Timur tentunya dipengaruhi oleh banyak faktor. Sukirno (2012) pertumbuhan ekonomi dipengaruhi oleh sumber daya alam yang dimiliki oleh provinsi Jawa Timur, jumlah penduduk dan kualitas sumber daya atau penduduk di provinsi Jawa Timur, tenaga kerja yang dimiliki oleh provinsi Jawa Timur, barang modal yang dimiliki oleh provinsi Jawa Timur serta teknologi yang ada dan dikembangkan oleh provinsi Jawa Timur.

Pemikiran Sukirno (2012) diantaranya didukung oleh penelitian Lubis dan Kodatie (2013) serta Wahyuni et al. (2013). Lubis dan Kodatie (2013) menyatakan bahwa pertumbuhan ekonomi dipengaruhi oleh tingkat teknologi yang digunakan dan dikembangkan dalam kegiatan ekonomi pada wilayah tersebut. Di provinsi DKI Jakarta 
tingkat teknologi memiliki pengaruh sebesar Rp 0,4 dapat dikatakan bahwa jika tingkat teknologi meningkat sebesar Rp 1 maka pertumbuhan ekonomi di provinsi DKI Jakarta akan meningkat sebesar Rp 0,4. Hasil penelitian ini juga didukung oleh penelitian Wahyuni et al. (2013) pada provinsi Aceh. Oleh karena itu dalam mendukung pertumbuhan ekonomi pemerintah Aceh akan terus mempertahankan dan meningkatkan teknologi yang digunakan dan berusaha mewujudkan peningkatan teknologi yang berkesinambungan sehingga di provinsi Aceh setiap tahunnya dapat dicapai pertumbuhan ekonomi. Teknologi ini dapat berupa peningkatan kualitas tingkat pendidikan sehingga tercipta motivasi untuk menghasilkan inovasi produk. Kondisi ini bukan hanya terjadi di beberapa provinsi saja di Indonesia, namun Takahito dan Kazuyuki (2009) guna meningkatkan perekonomian negara perlu adanya dukungan investasi yang besar bagi teknologi. Hal ini dikarenakan dengan teknologi yang maju dan tepat guna dapat memberikan dampak yang besar bagi perekonomian terutama dari sisi efisiensi penggunaan input. Namun tidak selamanya hal ini dapat diaplikasikan dengan wilayah lainnya. Kuntara (2016) mengemukakan di pulau Jawa secara agregat, penggunaan teknologi tidak mempengaruhi perekonomian secara keseluruhan, di pulau Jawa sendiri secara keseluruhan yang mempengaruhi adalah ICOR (incremental out put ratio) yang ada di pulau Jawa. Di provinsi Jawa Timur tingkat teknologi dapat dilihat di bawah ini:

Tabel 2

Tingkat Teknologi di Provinsi Jawa Timur

\begin{tabular}{cc}
\hline Tahun & Teknologi \\
\hline 2010 & 1.290 .545 \\
2011 & 1.148 .079 \\
2012 & 2.223 .988 \\
2013 & 3.616 .700 \\
2014 & 3.084 .603 \\
2015 & 3.634 .345 \\
2016 & 3.777 .392 \\
\hline
\end{tabular}

Sumber: BPS provinsi Jawa Timur (2010-2016)
Berdasarkan Tabel 2 dapat diketahui bahwa dari tahun 2010 ke 2011 tingkat teknologi mengalami penurunan sebesar Rp - 142.466. Pada tahun 2011 ke 2012 besarnya tingkat teknologi sebesar Rp 1.075.090. Pada tahun 2012 ke tahun 2013 besarnya tingkat teknologi sebesar $\operatorname{Rp} 1.392 .712$. Pada tahun 2013 ke tahun 2014 terjadi penurunan tingkat teknologi yaitu Rp -532.097. Pada tahun 2014 ke tahun 2015 terdapat peningkatan teknologi sebesar Rp 549.742. Pada tahun 2015 ke 2016 terdapat peningkatan teknologi sebesar Rp 143.047. Berdasarkan pemaparan dan Tabel 2 dapat diketahui bahwa besarnya tingkat teknologi di Provinsi Jawa Timur memiliki nilai yang berfluktuatif.

Sukirno (2012:49) menyatakan bahwa yang mempengaruhi pertumbuhan ekonomi selain teknologi adalah jumlah penduduk atau SDM. Jumlah penduduk dapat diartikan sebagai banyaknya jumlah penduduk yang terlibat dalam aktivitas perekonomian. Kondisi ini dapat dilihat dengan banyaknya jumlah usaha atau kegiatan ekonomi yang diupayakan oleh penduduk. Hal ini terlihat dari besarnya jumlah usaha mikro kecil menengah yang ada. Semakin banyak jumlah usaha mikro kecil menengah yang ada maka semakin banyak penduduk yang terlibat dalam kegiatan perekonomian serta semakin berkembang potensi lokal wilayah tersebut. Kondisi ini dapat meningkatkan perekonomian wilayah tersebut. Jika kondisi ini dapat diterapkan di provinsi Jawa Timur maka dapat mendukung pertumbuhan ekonomi. Hal ini selaras dengan penelitian yang dilakukan oleh Chughtai (2014), Taiwo et al. (2012) serta Budi (2010).

Pakistan merupakan salah satu negara yang pertumbuhan ekonominya dipengaruhi oleh jumlah usaha mikro kecil menengah. Pertambahan jumlah usaha mikro kecil menengah yang ada di Pakistan yang disertai dengan inovasi baik pada proses produksi, out put yang dihasilkan ataupun pelayanan yang diberikan memberikan pengaruh yang besar bagi pertumbuhan ekonominya (Chughtai, 2014). Bukan hanya di Pakistan saja, di negara Nigeria kontribusi 
usaha mikro kecil menengah juga memiliki pengaruh terhadap pertumbuhan ekonomi. Di Nigeria, pemerintah kurang memberikan perhatian kepada usaha mikro kecil menengah khususnya di bidang pengembangan usaha mikro kecil menengah. Oleh karena itu menurut Taiwo et al. (2012) jika pemerintah negara Nigeria ingin memiliki pertumbuhan ekonomi yang bagus maka pemerintah harus memberikan stimulus berupa kemudahan dalam akses permodalan. Dukungan yang diberikan pemerintah akan menimbulkan rangsangan bagi pelaku usaha mikro kecil menengah untuk dapat mengembangkan usaha yang dijalankan sehingga perekonomian dapat tumbuh. Di Indonesia sendiri khususnya di provinsi Jawa Tengah besarnya jumlah usaha mikro kecil menengah memberikan kontribusi yang besar bagi pertumbuhan ekonomi. Semakin banyak jumlah usaha mikro kecil menengah yang ada maka semakin tinggi tingkat pertumbuhan ekonominya (Budi, 2010). Namun, kondisi ini berbeda dengan kondisi yang ada di Kota Batu. Di Kota Batu yang memberikan pengaruh atau kontribusi bagi pertumbuhan ekonomi adalah modal yang dimiliki oleh pelaku usaha mikro kecil menengah serta laba yang didapatkan. Besarnya jumlah usaha mikro kecil menengah tidak memiliki pengaruh terhadap pertumbuhan ekonomi di Kota Batu. Besarnya jumlah usaha mikro kecil menengah di provinsi Jawa Timur dalam penelitian ini dilihat dari jumlah unit usaha yang terdapat di badan pusat statistik provinsi Jawa Timur. Jumlah unit usaha mikro kecil menengah dapat dilihat pada Tabel 3 dibawah ini:

Tabel 3

Jumlah usaha mikro kecil menengah

\begin{tabular}{cc}
\hline Tahun & $\begin{array}{c}\text { Jumlah Usaha Mikro } \\
\text { Kecil Menengah }\end{array}$ \\
\hline 2010 & 742.671 \\
2011 & 783.955 \\
2012 & 795.410 \\
2013 & 803.453 \\
2014 & 807.478
\end{tabular}

$2015 \quad 811.237$

$2016 \quad 813.237$

Sumber: BPS Jawa Timur 2011-2017

Berdasarkan Tabel 3 dapat diketahui bahwa jumlah usaha mikro kecil menengah yang ada di provinsi Jawa Timur cenderung mengalami peningkatan setiap tahunnya walaupun peningkatan jumlah usaha mikro kecil menengah ini tidak terlalu signifikan. Berdasarkan penjelasan diatas dapat diketahui bahwa adanya tingkat teknologi dan jumlah usaha mikro kecil menengah memberikan kontribusi bagi pertumbuhan ekonomi. Berdasarkan data yang ada dapat digambarkan hubungan antara jumlah usaha mikro kecil menengah dan tingkat teknologi terhadap pertumbuhan ekonomi di provinsi Jawa Timur pada Tabel 4 dibawah ini:

Tabel 4

Pertumbuhan ekonomi, Teknologi dan Jumlah Usaha Mikro Kecil Menengah

\begin{tabular}{crcc}
\hline \hline Tahun & $\begin{array}{c}\text { PDRB (dalam } \\
\text { juta Rp) }\end{array}$ & Teknologi & $\begin{array}{c}\text { Jumlah } \\
\text { Usaha } \\
\text { Mikro } \\
\text { Kecil } \\
\text { Menengah }\end{array}$ \\
\hline 2010 & 342.281 .000 & 1.290 .545 & 742.671 \\
2011 & 366.983 .000 & 1.148 .079 & 783.955 \\
2012 & 393.663 .000 & 2.223 .988 & 795.410 \\
2013 & 419.428 .000 & 3.616 .700 & 803.453 \\
2014 & 1.262 .684 .500 & 3.084 .603 & 807.478 \\
2015 & 1.331 .395 .000 & 3.634 .345 & 811.237 \\
2016 & 1.405 .236 .100 & 3.777 .392 & 813.237 \\
\hline
\end{tabular}

Sumber : BPS Jawa Timur 2011-2017

Berdasarkan Tabel 4 dapat diketahui bahwa selama tahun 2010-2016 besarnya teknologi cenderung mengalami peningkatan selama tujuh tahun begitu pula dengan jumlah usaha mikro kecil menengah besarnya cenderung mengalami peningkatan. Peningkatan jumlah usaha mikro kecil menengah dan teknologi disertai dengan peningkatan pertumbuhan ekonomi selama tujuh tahun yaitu dari tahun 2010 sampai tahun 2016. Berdasarkan penjelasan diatas maka rumusan masalah dalam penelitian ini 
bagaimana hubungan antara teknologi dan jumlah usaha mikro kecil menengah terhadap pertumbuhan ekonomi di provinsi Jawa Timur. Tujuan penelitian ini untuk melihat hubungan antara tingkat teknologi dan jumlah usaha mikro kecil menengah terhadap pertumbuhan ekonomi di Provinsi Jawa Timur

\section{TINJAUAN TEORETIS}

\section{Pertumbuhan Ekonomi}

Pertumbuhan ekonomi dan pembangunan ekonomi merupakan dua hal yang berbeda. Pertumbuhan ekonomi merupakan perkembangan fiskal yang dicapai oleh suatu daerah dalam memproduksi out put baik barang maupun jasa yang terus bertambah beserta pembangunan infrastruktur yang mendukung perekonomian. Pembangunan ekonomi merupakan pertumbuhan ekonomi yang diikuti dengan adanya perubahan pada struktur ekonomi. Misalnya awalnya perekonomian didominasi oleh sektor primer, maka pada suatu periode perekonomian di dominasi oleh sektor sekunder dan kemudian tersier. Besarnya pertumbuhan ekonomi suatu wilayah atau daerah dapat dilakukan dengan melihat besarnya produk domestik regional bruto (PDRB). Produk domestik regional bruto menggambarkan besarnya out put yang dihasilkan oleh suatu daerah baik berupa barang maupun jasa pada suatu periode tertentu (pada umumnya dalam satu tahun).

Terdapat tiga pendekatan yang digunakan untuk menghitung besarnya pertumbuhan ekonomi yaitu (Sukirno, 2012:39):

1. Pendekatan pendapatan

Pendekatan ini dilakukan dengan menjumlahkan semua pendapatan yang didapatkan oleh semua faktor produksi. Perhitungan pendapatan didasarkan pada penggolongan pendapatan yang diterima oleh faktor-faktor produksi sebagai berikut:
a. Pendapatan yang didapatkan para pekerja berupa upah dan gaji.
b. Pendapatan yang didapatkan dari usaha perseorangan. Merupakan jum-

lah gaji dan upah, bunga serta sewa dan laba yang diperoleh perusahaan dari usaha yang dijalankannya sendiri beserta keluarganya.

c. Pendapatan yang didapatkan dari sewa seperti sewa tanah, gedung dan lain sebagainya.

d. Pendapatan bunga neto yang merupakan pembayaran bunga dikurangi dengan bunga atas pinjaman yang dilakukan baik bunga pinjaman untuk konsumsi dan bunga atas pinjaman pemerintah.

2. Pendekatan pengeluaran

Pendekatan pengeluaran dilakukan dengan menjumlahkan seluruh pengeluaran yang dikeluarkan oleh aktivitas dalam perekonmian. Pendekatan perhitungan berdasarkan pengeluaran memberikan manfaat berupa:

a. Memberikan informasi mengenai sampai dimana buruknya masalah ekonomi yang dihadapi serta memberikan informasi mengenai tingkat pertumbuhan ekonomi yang sedang dicapai suatu negara serta memberikan informasi mengenai tingkat kemakmuran masyarakat suatu negara;

b. Pendekatan ini dapat memberikan data yang dibutuhkan dalam menetapkan kebijakan makro ekonomi sera informasi yang dibutuhkan.

Perhitungan ini dilakukan dengan menjumlahkan empat komponen dalam perekonomian yaitu konsumsi rumah tangga, pegeluaran pemerintah, pembentukan modal sektor swasta serta ekspor neto. Konsumsi rumah tangga merupakan besarnya belanja yang dikeluarkan oleh rumah tangga untuk membelanjakan atau memenuhi kebutuhannya dalam satu tahun tertentu. Pengeluaran pemerintah dilakukan untuk memenuhi kebutuhan pemerintah dan untuk memenuhi kebutuhan masyarakat. Belanja pemerintah dibagi menjadi dua yaitu belanja untuk konsumsi dan belanja untuk investasi. Pembentukan modal 
tetap sektor swasta merupakan belanja yang dilakukan dengan tujuan untuk membeli barang modal yang dapat meningkatkan out put barang atau jasa. Ekspor neto merupakan besarnya nilai ekspor yang dilakukan oleh suatu negara dikurangi dengan besarnya nilai impor yang dilakukan oleh suatu negara. Dalam pendekatan pengeluran ini besarya perhitungan pendapatan dapat dilakukan dengan cara $\mathrm{Y}=\mathrm{C}+\mathrm{I}+\mathrm{G}+\mathrm{X}-\mathrm{M}$. Dimana $\mathrm{Y}$ merupakan pendapatan nasional, $\mathrm{C}$ merupakan konsumsi rumah tangga, $G$ merupakan belanja pemerintah dan X-M merupakan ekspor neto.

3. Pendekatan nilai tambah

Pendekatan ini dilakukan dengan cara menambahkan secara keseluruhan nilai tambah yang di hasilkan oleh perusahaan pada berbagai sektor lapangan usaha dalam suatu perokonomian. Adapun manfaat perhitungan dengan menggunakan pendekatan ini adalah untuk:

a. Mengetahui besarnya sumbangan berbagai sektor lapangan usaha dalam kegiatan perekonomian guna mewujudkan pendapatan nasional.

b. Yang terpenting adalah untuk menghindarkan masalah perhitungan yang dobel. Pada pendekatan ini hanya dilakukan perhitungan nilai produksi neto yang dihasilkan pada setiap proses produksi.

Di Indonesia perhitungan dengan pendekatan ini dilakukan dengan cara menjumlahkan mengelompokkan dari berbagai sektor yang menghasilkan nilai tambah. Di Indonesia sendiri terdapat tiga sektor dalam perekonomian yaitu:

a. Sektor primer yang terdiri dari sektor pertanian, peternakan, kehutanan, perikanan dan pertambangan serta penggalian

b. Sektor sekunder, yang terdiri dari industri pengelolaan; listrik, air, dan gas; bangunan.

c. Sektor tersier, yang terdiri dari perdagangan, hotel dan restoran; pengangkutan dan komunikasi; keuangan, sewa dan jasa perusahaan; serta jasajasa yang lainnya.

\section{Teori Solow}

Model pertumbuhan ekonomi Solow Swan atau yang dikenal juga dengan model neo klasik dikemukakan oleh Robertsolow dan Trevor Swan pada tahun 1950. Analisis model pertumbuhan ekonomi Solow Swan merupakan model analisis pertumbuhan ekonomi jangka panjang. Model Solow Swan menyatakan bahwa tingkat pertumbuhan ekonomi suatu negara berasal dari interaksi antara akumulasi modal, bertambahnya jumlah penawaran tenaga kerja serta kemajuan teknoligi (Kurniawan et al., 2015). Teknologi dalam model ini dapat dilihat dari peningkatan skill yang ada dalam suatu kegiatan ekonomi sehingga dapat meningkatkan produktivitas. Dalam model Solow Swan ini teknologi merupakan suatu fungsi waktu. Dimana waktu akan masuk dalam fungsi produksi melalui kapital (K), tenaga keja (L) dan teknologi (A). Kondisi ini dapat ditunjukkan pada model dibawah ini:

$$
\mathrm{Y}(\mathrm{t})=\mathrm{F}[\mathrm{K}(\mathrm{t}), \mathrm{L}(\mathrm{t}), \mathrm{A}(\mathrm{t})]
$$

Dengan adanya teknologi dalam suatu perekonomian dapat meningkatkan out put melalui peningkatan produktivitas input input. Artinya dengan adanya teknologi yang ada suatu perekonomian dapat berproduksi lebih efisien dan tingkat out put yang dihasilkan akan menjadi semakin meningkat. Namun peningkatan out put yang disebabkan oleh akumulasi modal dan tenaga kerja akan meningkat terhadap waktu jika terdapat peningkatan pada ilmu pengetahuan (Sulaiman, 2013).

Terdapat suatu asumsi yang penting berkaitan dengan fungsi produksi yaitu constan return to scale, dimana capital dan effective labor, dengan menggandakan jumlah capital dan tenaga kerja yang efektif dan nilai teknologi yang tetap dapat memberikan dampak menggandakan jumlah produksinya. Jika mengkalikan variabel tenaga kerja dan modal dengan konstanta $\mathrm{c}$ dapat berakibat out put berubah dengan tingkat yang sama yaitu $\mathrm{F}(\mathrm{cK}, \mathrm{cL})=\mathrm{cF}(\mathrm{K}, \mathrm{AL})$. 
Asumsi constan return to scale merupakan kombinasi dari asumsi bahwa:

a. Perekonomian merupakan suatu hal yang cukup besar, dimana perolehan dari spesialisnya telah digunakan secara keseluruhan. Suatu negara yang memiliki perekonomian yang lebih kecil terdapat kemungkinan bahwa akan dilakukan spesialisasi lebih lanjut yang akan menggandakan jumlah modal dan tenaga kerja. Pada suatu perekonomian yang cukup besar jika besarnya modal dan tenaga kerja di lipat gandakan maka tingkat out put juga akan berlipat ganda.

b. Tidak ada input yang lebih penting bagi pertumbuhan ekonomi selain tenaga kerja, modal dan pengetahuan.

\section{Teori Harrod Domar}

Analisis Harrod Dormar didasarkan pada tiga asumsi. Pertama yaitu barang modal telah mencapai kapasitas penuh, kedua yaitu nilai tabungan proporsional dengan pendapatan nasional, ketiga yaitu besarnya rasio modal produksi memiliki nilai yang tetap dan perekonomian terdiri dari dua sektor (Mankiw, 2006:221).

Berdasarkan teori Harrod Domar, pada setiap kegiatan perekonomian, dapat disisihkan sebagian pendapatan yang didapatkan untuk mengganti barang modal rusak (Todaro, 1997:65)

Guna meningkatkan pertumbuhan ekonomi diperlukan suatu investasi yang baru yang merupakan tambahan netto terhadap stok modal. Jika diasumsikan adanya ketertarikan antara besarnya stok modal keseluruhan dengan GNP maka adanya setiap tambahan stok neto terhadap stok modal dalam bentuk investasi akan menghasilkan kenaikan aliran out put nasional.

Jika rasio modal atau out put (k) dan rasio tabungan nasional (s) adalah bagian out put yang tetap dari out put nasional dan besarnya investasi baru ditentukan oleh jumlah tabungan maka model sederhana pertumbuhan ekonomi adalah a. Tabungan (S) $S=$ s.Y.(1) dimana tabungan adalah bagian dari pendapatan nasional.

b. Investasi diartikan sebagi perubahan stok modal $\mathrm{K}$ yang ditunjukkan oleh $\mathrm{I}=\Delta \mathrm{K}_{(2)}$

c. Karena jumlah keseluruhan tabungan nasional (S) harus sama dengan keseluruhan investasi (I) maka S=I. (3)

d. Dari persamaan diatas maka didapatkan persamaan berikut : $\frac{\Delta Y}{Y}=\frac{s}{k}$ (4)

e. Dari persamaan 4 dapat diketahui bahwa tingkat pertumbuhan GNP ditentukan secara bersama-sama oleh rasio tabungan nasional (s) dan rasio modal atau output nasional (k). Persamaan 4 menyatakan bahwa pertumbuhan pendapatan nasional berhubungan positif dengan rasio tabungan, sehingga semakin besar bagian dari GNP yang ditabung dan diinvestasikan maka semakin besar pertumbuhan GNP tersebut.

\section{Usaha Mikro Kecil Menengah}

Definisi usaha mikro kecil menengah berdasarkan Undang - Undang No. 20 tahun 2008 Tentang Usaha Mikro Kecil Menengah adalah:

a. Usaha mikro adalah usaha produktif milik orang perorangan atau badan usaha perorangan yang memenuhi kriteria usaha mikro sebagaimana diatur dalam Undang-Undang ini.

b. Usaha kecil usaha ekonomi produktif yang berdiri sendiri, yang dilakukan oleh orang perorangan atau badan usaha yang bukan merupakan anak perusahaan atau bukan cabang perusahaan yang dimiliki, dikuasai, atau menjadi bagian baik langsung maupun tidak langsung dari usaha menengah atau usaha besar yang memenuhi kriteria Usaha Kecil sebagaimana dimaksud dalam Undang-Undang.

c. Usaha menegah adalah usaha ekonomi produktif yang berdiri sendiri, yang dilakukan oleh orang perorangan atau badan usaha yang bukan merupakan anak perusahaan atau cabang perusahaan yang dimiliki, dikuasai, atau menjadi bagian baik langsung maupun tidak 
langsung dengan usaha kecil atau usaha besar dengan jumlah kekayaan bersih atau hasil penjualan.

Usaha mikro kecil menengah memiliki karakteristik yang berbeda dengan usaha besar, dimana usaha mikro kecil menengah memiliki karakteristik sebagai berikut (Rahman, 2016):

a. Terdapat banyak sekali jumlah usaha mikro kecil menengah dan tersebar di berbagai wilayah mulai perkotaan hingga wilayah pedesaan.

b. Bersifat padat karya sehingga memiliki potensi untuk meningkatkan pertumbuhan kesempatan kerja

c. Pada umumnya kegiatan usaha mikro kecil mengah berbasiskan kegiatan pertanian. Hal ini khusus kegiatan usaha mikro kecil menengah yang berada di wilayah perdesaan.

d. Usaha mikro kecil menengah menggunakan teknologi yang lebih cocok terhadap proporsi dari faktor produksi dan kondisi lokal yang terdapat pada negara yang sedang berkembang.

e. Biasanya usaha mikro kecil menengah tumbuh dengan pesat dan tahan terhadap kiris ekonomi. Hal ini dikarenakan usaha mikro kecil menengah merupakan usaha yang berbasiskan potensi lokal.

f. Usaha mikro kecil menengah sebagian besar merupakan titik awal bagi masyarakat untuk mobilisasi bagi investasi di pedesaan.

g. Sebagian besar modal usaha mikro kecil menengah berasal dari tabungan pribadi pemiliki usaha mikro kecil menengah.

h. Sebagain besar barang produksi usaha mikro kecil menengah adalah barang konsumsi dan non konsumsi dengan harga yang relatif terjangkau

i. Terdapat banyak usaha mikro kecil menengah mampu meningkatkan produktivitasnya melalui investasi dan perubahan teknologi.

j. Usaha mikro kecil menengah memiliki tingkat fleksibilitas yang tinggi terhadap para pesaingnya.
Di Indonesia, usaha mikro kecil mengah jika dilihat dari perspektif perkembangannya dikelompokkan menjadi empat yaitu Latumerisa (2015):

a. Livelihood activities, merupakan usaha yang dijalankan digunakan sebagi lahan utama untuk mencari nafkah. Biasanya usaha mikro kecil menengah berbentuk usaha informal.

b. Micro enterprise, usaha mikro kecil menengah memiliki sifat pengrajin namun belum memiliki sifat kewirausahaan.

c. Small dynamic enterprise, usaha mikro kecil menengah telah memiliki jiwa kewirausahaan serta mampu menerima pekerjaan sub kontrak dan bersifat ekspor.

d. Fast moving enterprise, usaha mikro kecil menengah telah memiliki jiwa kewirausahaan serta mampu melakukan transformasi menjadi usaha besar.

Menurut Latumerisa (2015) karakteristik usaha mikro kecil menengah dapat dijabarkan sebagai berikut:

a) Karakteristik usaha mikro adalah sebagai berikut:

1. Jenis barang atau komoditi usahanya tidak selalu tetap.

2. Tempat usahanya tidak selalu menetap.

3. Belum melakukan administrasi keuangan sederhana dan tidak memisahkan keuangan keluarga dan usaha.

4. SDM nya belum memiliki jiwa kewirausahaan yang memadai.

5. Tingkat pendidikan rata-rata relative sangat rendah.

6. Umumnya belum akses ke perbankan namum sebagian sudah ke lembaga keuangan non bank.

7. Umumnya tidak memiliki ijin usaha atau legalitas.

b) Karakteristik usaha kecil adalah sebagai berikut:

1. Jenis barang atau komoditi yang diusahakan umumnya sudah tetap tidak gampang berubah.

2. Lokasi atau tempat usaha umumnya menetap dan tidka berpindah. 
3. Sudah melakukan administrasi keuangan walaupun sederhana.

4. Sudah memiliki izin usaha dan persyaratan legalitas lainnya.

5. SDM memiliki pengalaman dalam berwirausaha.

6. Sebagian sudah mempunyai akses keperbankan untuk keperluan modal.

7. Sebagian belum mampu membuat manajemen usaha dengan baik seperti business planning.

c) Karakteristik usaha menengah adalah sebagai berikut:

1. Umumnya memiliki manajemen dan organisasi yang lebih baik, teratur, modern dengan pembagian tugas.

2. Sudah melakukan manajemen keuangan dengan menerapkan system akuntansi dengan teratur.

3. Telah melakukan aturan atau pengelolaan dan organisasi perburuhan.

4. Sudah memiliki segala persyaratan legalitas.

5. Sudah memiliki akses terhadap sumber pendanaan perbankan.

6. Umumnya memiliki SDM yang terlaih dan terdidik.

\section{Hubungan Antar Variabel}

Hubungan Antara Jumlah Usaha Mikro Kecil Menengah Dengan Pertumbuhan Ekonomi

Jumlah penduduk merupakan salah satu aset yang dimiliki oleh suatu daerah. Jumlah penduduk yang dimiliki dapat menggambarkan jumlah tenaga kerja yang dimiliki daerah tersebut. Tenaga kerja yang efektif merupakan tenaga kerja yang dapat memberikan kontribusi bagi kegiatan ekonomi suatu daerah. Jumlah penduduk dapat pula digambarkan sebagai banyaknya jumlah penduduk yang bergerak dalam usaha mandiri berskala kecil. Di Indonesia hal ini dikenal dengan usaha mikro kecil menengah (usaha mikro kecil menengah). semakin banyak jumlah penduduk yang terjun dalam usaha mikro kecil menengah maka semakin banyak tenaga kerja yang terserap dan semakin besar potensi ekonomi lokal yang dapat diolah. Hal ini dikarenakan usaha mikro kecil menengah merupakan jenis industri yang membutuhkan banyak tenaga kerja serta bahan baku yang digunakan berasal dari wilayah tersebut. Berdasarkan penjelasan diatas dapat disimpulkan bahwa semakin banyak jumlah usaha mikro kecil menengah maka semakin meningkat pertumbuhan ekonomi daerah tersebut.

Penjelasan diatas sesuai dengan hasil penelitian yang dilakukan oleh Budi (2010) di provinsi Jawa Tengah, dimana jumlah usaha mikro kecil menengah yang ada memiliki hubungan yang positif terhadap produk domestik regional bruto (PDRB), sehingga dapat dikatakan bahwa semakin banyak jumlah usaha mikro kecil menengah maka semakin meningkat PDRB di provinsi Jawa Tengah. Hal tersebut senada dengan penelitian yang dilakukan oleh Chughtai (2014) usaha mikro kecil menengah merupakan salah satu usaha yang dapat mendorong pertumbuhan ekonomi di Pakistan. Semakin banyak inovasi yang dilakukan oleh usaha mikro kecil menengah maka semakin maju usaha mikro kecil menengah, kemajuan usaha mikro kecil menengah ini akan berdampak pada pertumbuhan ekonomi di Pakistan. Hapsari et al., (2014) pada kota Batu justru jumlah usaha mikro kecil menengah tidak memiliki pengaruh pada PDRB. Pada kota Batu yang mempengaruhi besarnya PDRB adalah pemberdayaan usaha mikro kecil menengah, modal yang dimiliki oleh usaha mikro kecil menengah serta laba yang didapatkan oleh usaha mikro kecil menengah.

\section{Hubungan Antara Teknologi dan Per- tumbuhan Ekonomi.}

Berdasarkan penjelasan pada teori Solow diketahui bahwa kemajuan teknologi akan membawa pengaruh pada pertumbuhan ekonomi, kemajuan teknologi merupakan pengetahuan masyarakat akan metode-metode produksi. 
Hal ini digambarkan pada tingkat efisiensi tenaga kerja. Dengan adanya teknologi, tenaga kerja dengan jumlah yang sama dapat memproduksi lebih banyak out put karena tingkat produksi yang semakin efisien. Semakin banyak out put yang dihasilkan pada perekonomian suatu daerah, maka semakin besar atau meningkat PDRB yang dapat dihasilkan oleh daerah tersebut.

Penjelasan tersebut sejalan dengan penelitian yang dilakukan oleh Lubis dan Kodatie (2013) teknologi yang ada mempunyai pengaruh yang signifikan pada PDRB provinsi DKI Jakarta. Dalam penelitian tersebut ditemukan bahwa setiap ada kenaikan teknologi yang ada sebesar Rp 1 maka PDRB akan meningkat sebesar Rp 0,14 . Oleh karena itu dapat diketahui bahwa semakin besar dan maju teknologi yang ada maka semakin besar pendapatan yang akan didapatkan oleh suatu daerah.

Hal yang sama juga didapatkan oleh Wahyuni et al. (2013) di provinsi Aceh adanya pertumbuhan dan pengembangan teknologi sangat penting pengaruhnya bagi pertumbuhan ekonomi di provinsi Aceh. Mengingat hal tersebut maka penting kiranya bagi pemerintah Aceh untuk mengembangkan teknologi dan pengetahuan serta meningkatkan kemajuan teknologi secara berkesinambungan sehingga pertumbuhan ekonomi di provinsi Aceh dapat terus meningkat.

\section{Perumusan Hipotesis}

Berdasarkan penjelasan keterkaitan antar variabel dapat diketahui bahwa pada beberapa wilayah seperti di Provinsi Jawa Tengah dan di negara Pakistan jumlah usaha mikro kecil menengah memiliki pengaruh pada PDRB namun tidak pada kota Batu. Berdasarkan penjelasan diatas karena itu dapat dirumuskan suatu hipotesis sebagai berikut:

$\mathrm{H}_{1}=$ Terdapat hubungan yang signifikan antara jumlah usaha mikro kecil menengah dengan pertumbuhan ekonomi
Efektivitas tenaga kerja dalam kegiatan produksi juga berpengaruh terhadap tingkat out put yang dihasilkan. Meningkatnya efektifitas ini dikarenakan dengan teknologi yang ada, sehingga dengan jumlah tenaga kerja tetap maka tingkat out dapat meningkat. Oleh karena itu dapat dirumuskan suatu hipotesis sebagai berikut:

$\mathrm{H}_{2}=$ Terdapat hubungan yang signifikan antara teknologi dengan pertumbuhan ekonomi

\section{Rerangka Hubungan Antar Variabel}

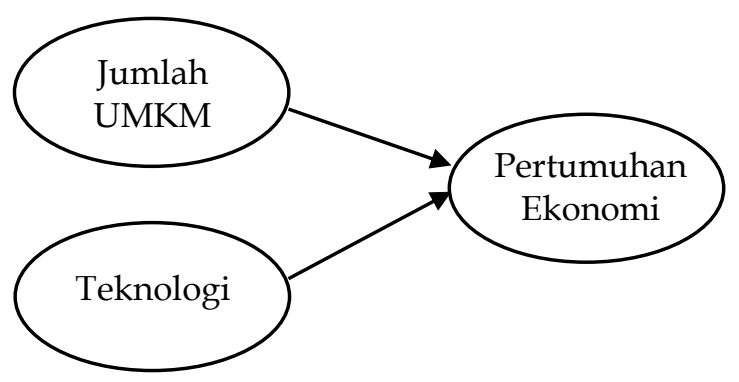

\section{Gambar 1 \\ Hubungan Antar Variabel}

\section{METODE PENELITIAN Variabel Penelitian}

Dalam penelitian ini terdapat tiga variabel yang digunakan. Variabel independen dalam penelitian ini adalah teknologi dan jumlah usaha mikro kecil menengah. Variabel dependen dalam penelitian ini adalah pertumbuhan ekonomi di provinsi Jawa Timur.

\section{Definisi Operasional}

Adapun definisi operasional adalah:

a. Pertumbuhan ekonomi

Merupakan besarnya out put yang dihasilkan baik berupa barang ataupun jasa selama periode satu tahun. Besarnya out put yang dihasilkan dapat dilihat dari besarnya produk domestik regional bruto (PDRB) provinsi Jawa Timur sektor lapangan usaha berdasarkan harga konstan. Pertumbuhan ekonomi di lihat dari besarnya produk domestik regional bruto berdasarkan harga konstan di- 
karenakan produk domestik regional bruto ini menggambarkan besarnya nilai tambah yang dihasilkan dalam setiap proses produksi dimana nilainya tidak dipengaruhi oleh perubahan tingkat harga (inflasi) (Sukirno, 2012).

b. Teknologi

Tingkat teknologi pada penelitian merupakan besarnya modal per tenaga kerja. Jadi untuk mencari besarnya tingkat teknologi dilakukan dengan cara: Modal

Tenaga Kerja yang Sedang Bekerja

Modal dalam penelitian ini di dapatkan dari besarnya nilai investasi domestik dan nilai investasi asing di provinsi Jawa Timur. Nilai investasi asing dalam penelitian ini diubah nilainya dalam bentuk Rupiah (Lubis dan Kodatie, 2013).

c. Jumlah usaha mikro kecil menengah:

Pada penelitian ini, jumlah usaha mikro kecil menengah dilihat dari besarnya jumlah unit usaha yang ada di provinsi Jawa Timur yang terdapat dalam data Badan Pusat Statistik provinsi Jawa Timur (BPS, 2010).

Jenis, Sumber Data dan Metode Pengumpulan Data

Jenis data yang digunakan dalam penelitian ini untuk mengukur hubungan variabel dependen dengan variabel independen adalah data sekunder yang di dapatkan dari Badan Pusat Statistik (BPS) Provinsi Jawa Timur.

Metode pengumpulan data yang digunakan dalam penelitian ini adalah metode dokumen. Dalam penelitian ini data didapatkan dari laporan publikasi yang ada di Badan Pusat Statistik Provinsi Jawa Timur. Laporan publikasi yang digunakan yaitu pada tahun 2000 sampai dengan tahun 2016.

\section{Metode Analisis Data}

Pada penelitian ini, metode analisis yang digunakan adalah analisis regresi linier berganda. Dikatakan analisis regresi linier berganda dikarenakan menggunakan lebih dari satu variabel independen dalam penelitian ini. Model estimasi yang digunakan untuk membentuk persamaan regresi adalah metode ordinary least square. Persamaan model dalam penelitian ini adalah:

$$
Y=\alpha+\beta_{1} J U M+\beta_{2} T+\mu
$$

Keterangan:

$\mathrm{Y}=$ Pertumbuhan ekonomi yang dilihat dari PDRB berdasarkan harga kosntan,

$\mathrm{T}=$ Teknologi

$\mathrm{JUM}=$ Jumlah usaha mikro kecil menengah yang ada di provinsi jawa timur.

$\mathrm{a}=$ Konstanta

$\beta_{1}=$ Koefisien pada variabel independen jumlah UMKM

$\beta_{2}=$ Koefisien pada variabel independen Teknologi

$\mu \quad=$ Standar error

\section{Uji Asumsi Klasik}

\section{Uji Multikolinearitas}

Uji ini digunakan untuk menguji apakah ada atau tidak korelasi antara variabel independen dalam model regresi, artinya ada hubungan linear antar variabel independen dalam model regresi. Yang mana bila terjadi korelasi antar variabel independen, maka model regresi menjadi bias. Nilai cut off yang umumnya dipakai untuk menunjukkan bahwa semua variabel bebas tidak mempunyai masalah multikolinearitas adalah nilai tolerance $>0,10$ atau nilai VIF $<$ 10.

\section{Uji Heteroskedastisitas}

Tujuan uji ini adalah untuk mengetahui apakah variance dari residual data satu observasi ke observasi lainnya berbeda atau tetap, jika variance dari residual data sama disebut homokedastisitas dan jika berbeda disebut heterokedastisitas. Metode uji heteroskedastisitas dengan menggunakan korelasi Spearman's rho yaitu mengkore lasikan variabel independen dengan nilai unstandardized residual dengan ketentuan sebagai berikut: 
a. Bila nilai sig $\geq 5 \%$, maka Ho diterima dan $\mathrm{H}_{1}$ ditolak, artinya tidak ada heteroskedastisitas.

b. Bila nilai sig < 5\%, maka H0 ditolak dan $\mathrm{H}_{1}$ diterima, artinya ada heteroskedastisitas.

\section{Uji Autokorelasi}

Digunakan untuk menguji apakah dalam suatu model regresi linier terdapat korelasi antar kesalahan variabel penganggu pada periode $t$ dengan kesalahan pada periode $\mathrm{t}-1$. Autokorelasi biasanya muncul dikarenakan observasi yang berurutan sepanjang waktu berkaitan satu dengan yang lain. Masalah ini timbul biasanya pada data time series. Model dikatakan lolos uji autokorelasi jika nilai DW terletak antara batas atas dan batas bawah (4-du), yang berarti koefisien autokorelasi sama dengan nol, sehingga model dikatakan bebas dari autokorelasi

\section{Uji Normalitas}

Uji ini dilakukan untuk menguji apakah dalam model regresi variabel penganggu atau residual mempunyai distribusi normal. Hal ini penting dilakukan karena jika asumsi ini dilanggar maka uji statistik menjadi tidak valid untuk jumlah sampel yang sangat kecil.

\section{Uji Hipotesis}

\section{Uji F}

Uji F digunakan untuk menguji model regresi (goodness of fit). Dimana Uji F juga digunakan untuk mengetahui seberapa besar variabel-variabel independen menjelaskan variabel dependen dalam model yang diuji, dengan menggunakan tingkat signifikansi $a=5 \%$. Dimana pengambilan keputusan berdasarkan ketentuan berikut:

a. Jika nilai signifikan $\geq 0,05$, maka H0 diterima dan $\mathrm{H}_{1}$ ditolak yang berarti variabel independen tidak berpengaruh secara simultan terhadap variabel dependen atau model tidak layak.

b. Jika nilai signifikan $<0,05$ maka $\mathrm{H}_{0}$ ditolak dan $\mathrm{H}_{1}$ diterima yang berarti variabel independen berpengaruh secara simultan terhadap variabel dependen atau model layak.

\section{Uji t}

Uji ini dilakukan dengan membandingkan nilai signifikansi dengan $\alpha=0,05$. Pengambilan keputusan berdasarkan ketentuan berikut:

a) Jika nilai signifikan $\geq 0,05$, maka $\mathrm{H}_{0}$ diterima dan $\mathrm{H}_{1}$ ditolak yang berarti variabel independen tidak berpengaruh secara parsial terhadap variabel dependen.

b) Jika nilai signifikan $<0,05$ maka $\mathrm{H}_{0}$ ditolak dan $\mathrm{H}_{1}$ diterima yang berarti variabel independen berpengaruh secara parsial terhadap variabel dependen.

\section{Koefisien Determinasi}

Uji dilakukan untuk melihat seberapa jauh suatu model mampu menerangkan variasi variabel dependen. Nilai koefisien determinasi adalah antara nol dan satu. Jika $\mathrm{R}^{2}$ kecil maka kemampuan variabel independen dalam menjelaskan variabel dependen amat terbatas. Jika nilai $\mathrm{R}^{2}$ mendekati satu maka varaibel independen yang digunakan mampu menjelaskan variabel dependen atau variabel independen yang digunakan mampu memprediksi variasi variabel dependen. Pada data silang $\mathrm{R}^{2}$ relatif rendah dikarenakan adanya variasi yang besar antar masing-masing pengama$\tan ($ Ghozali,2009).

\section{ANALISIS DAN PEMBAHASAN \\ Analisis}

Berdasarkan hasil analisis yang telah dilakukan maka dapat dijelaskan sebagai berikut:

\section{Uji Asumsi Klasik}

Uji asumsi klasik dilakukan untuk mengetahui bahwa persamaan regresi yang didapatkan memiliki ketepatan dalam estimasi dan konsisten. Adapun hasil uji asumsi klasik dapat dijelaskan pada hasil uji normalitas, uji multikolinearitas, uji heteros- 
kedastisitas serta uji autokorelasi di bawah ini:

\section{a) Uji Normalitas}

Uji normalitas pada penelitian ini didasarkan pada Gambar 2 grafik normal plot dibawah ini. Berdasarkan Gambar dua dapat dilihat bahwa titik-titik menyebar disekitar garis diagonal serta penyebarannya mengikuti arah dari garis diagonal. Berdasarkan kondisi tersebut dapat dikatakan bahwa model regresi yang dihasilkan telah memenuhi uji normalitas. Kondisi ini dapat dilihat pada Grafik 2 di bawah ini:

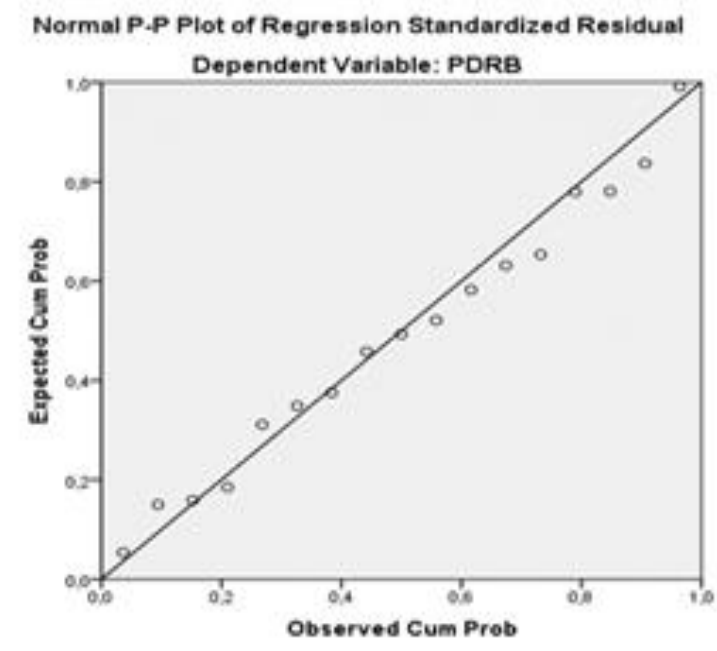

Gambar 2

Uji Normalitas

Sumber : Data Sekunder diolah

Berdasarkan Gambar 2 model ini memenuhi uji normalitas sehingga model yang digunakan mempunyai residual yang terdistribusi secara normal. Berdasarkan Gambar 2 dapat disimpulkan model yang dihasilkan dapat digunakan sebagai alat estimasi.

\section{b) Uji Multikolinearitas}

Uji multikolinearitas pada penelitian ini dilakukan untuk mengetahui apakah pada model terdapat keterkaitan antar variabel independen. Uji multikolinearitas dapat diketahui dengan melihat nilai variance inflation factor (VIF). Nilai cut off yang dipakai untuk menunjukkan bahwa semua variabel bebas tidak mempunyai masalah multikolinearitas adalah nilai tolerance $>0,10$ atau nilai VIF $<10$. Pada penelitian ini variabel teknologi memiliki nilai tolerance $0,610>0,10$ dan VIF 1,640 < 10, sehingga dalam penelitian ini dapat dikatakan bahwa variabel teknologi bebas dari multikolinearitas. Pada variabel jumlah usaha mikro kecil menengah memiliki nilai tolerance sebesar $0,610>0,10$ dan VIF 1,64 < 10, sehingga dalam penelitian ini dapat dikatakan bahwa variabel jumlah usaha mikro kecil menengah juga terbebas dari multikolinearitas. Berdasarkan pemaparan diatas dapat diketahui bahwa pada model yang dihasilkan tidak terdapat keterkaitan antar variabel independen.

\section{c) Uji Heteroskedastisitas}

Uji ini dilakukan untuk melihat apakah dalam model terdapat ketidaksamaan variance dari residual satu pengamatan ke pengamatan yang lainnya. Pada penelitian ini untuk mendeteksi heteroskedastisitas didasarkan pada grafik scatterplot. Berdasarkan gambar 3 dibawah ini dapat dilihat bahwa titik menyebar secara acak serta tersebar baik diatas maupun dibawah angka 0 pada sumbu $Y$ sehingga dapat dikatakan bahwa model regresi tidak mengandung masalah heteroskedastisitas.

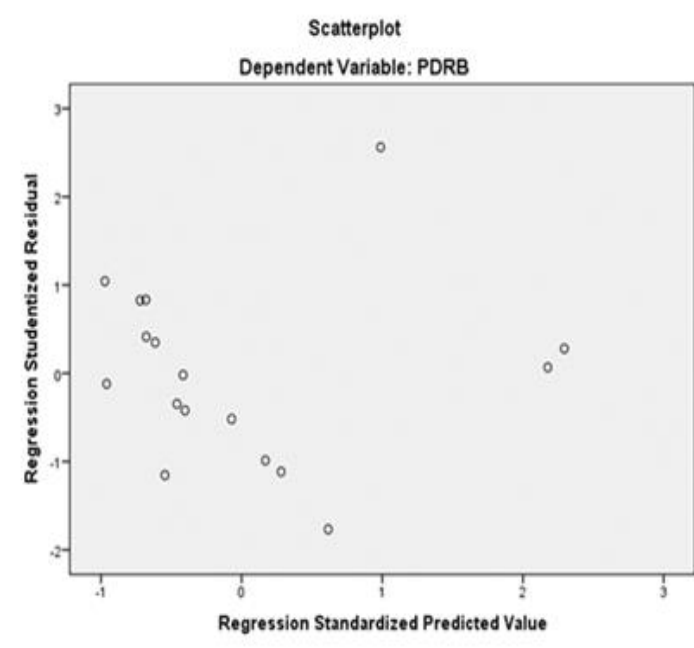

\section{Gambar 3}

Grafik Scatterplo

Sumber : Data Sekunder 


\section{Uji Autokorelasi}

Uji ini digunakan untuk menguji apakah model yang dihasilkan terdapat korelasi kesalahan penganggu pada periode $t$ dengan kesalahan penganggu pada periode sebelumnya. Untuk pengujian autokorelasi dilakukan dengan menggunakan uji durbin Watson (Ghozali, 2009). Pada uji ini nilai durbin Watson sebesar 1,971 sedangkan nilai $\mathrm{d}_{\mathrm{L}}$ 0,857 dan $\mathrm{d}_{\mathrm{U}}$ sebesar 1,728. Berdasarkan kondisi tersebut dapat diketahui bahwa model regresi yang dihasilkan terbebas dari autokorelasi.

\section{Uji Hipotesis}

Tujuan dari dilakukannya uji hipotesis adalah untuk membuktikan apakah hipotesis yang diajukan terbukti atau tidak terbukti. Hasil uji hipotesis dapat dilihat pada Tabel 5 dibawah ini:

Tabel 5

Hasil Uji Model Regresi

\begin{tabular}{lrc}
\hline Variabel & Koefisien & Probabilitas \\
\hline Y & -13053 & 0,19 \\
T & 0,682 & 0,00 \\
JUM & 0,329 & 0,024 \\
R square adj & 0,834 & \\
Prob F statistic & 41,1211 & 0,00 \\
\hline
\end{tabular}

Sumber: data diolah, 2017

\section{Uji F}

Uji ini dilakukan untuk melihat apakah semua variabel independen yang digunakan pada model memiliki pengaruh secara bersama-sama terhadap variabel dependen. Berdasarkan analisis regresi dapat diketahui bahwa nilai $F$ sebesar 41,211 dengan signifikansi sebesar 0,000 sehingga dapat dikatakan bahwa semua variabel independen yaitu tingkat teknologi dan jumlah usaha mikro kecil menengah dalam model yang dihasilkan memiliki pengaruh secara bersama-sama terhadap variabel dependen yaitu pertumbuhan ekonomi provinsi Jawa Timur.

\section{Uji t}

Uji t pada dasarnya dilakukan untuk melihat seberapa jauh pengaruh masingmasing variabel independen dalam menerangkan variabel dependen. Pada penelitian ini dapat diketahui bahwa variabel tingkat teknologi memiliki nilai probabilitas sebesar 0,000, yaitu kurang dari 5\% sehingga dapat dikatakan bahwa variabel tingkat teknologi memiliki pengaruh terhadap pertumbuhan ekonomi di provinsi Jawa Timur. Pada variabel jumlah usaha mikro kecil menengah memiliki probablitas sebesar 0,024 yaitu kurang dari 5\% sehingga dapat dikatakan bahwa variabel jumlah usaha mikro kecil menengah memiliki pengaruh terhadap pertumbuhan ekonomi di provinsi Jawa Timur. Berdasarkan penjelasan diatas, dapat diketahui bahwa masing-masing variabel independen dalam penelitian ini memiliki pengaruh terhadap pertumbuhan ekonomi di provinsi Jawa Timur.

\section{Koefisien Determinasi}

Koefisien determinasi ini digunakan untuk melihat seberapa jauh kemampuan model dalam menerangkan variabel dependen. Pada penelitian ini dapat diketahui bahwa nilai koefisien determinasi yang telah disesuaikan sebesar 0,834 yang berarti model yang dihasilkan dapat menerangkan variabel dependen sebesar 83,4\% sedangkan $16,6 \%$ kondisi variabel dependen yaitu pertumbuhan ekonomi di provinsi Jawa Timur diterangkan oleh variabel independen yang lain selain tingkat teknologi dan jumlah usaha mikro kecil menengah.

\section{Model Penelitian}

Berdasarkan Tabel 5 diatas didapatkan model penelitian dibawah ini yaitu:

$\mathrm{Y}=-13053+0,682 \mathrm{~T}+0,329 \mathrm{JUM}+\mathrm{e}$

Berdasarkan persamaan 2 diatas dapat diketahui bahwa koefisien teknologi memiliki koefisien sebesar 0,682 dimana jika tingkat teknologi di provinsi Jawa Timur meningkat dan berkembang sebesar $\mathrm{Rp} 1$ maka pertumbuhan ekonomi di provinsi Jawa Timur akan meningkat sebesar Rp 
0,682. pada variabel jumlah usaha mikro kecil menengah memiliki koefisien sebesar 0,329 dimana jika jumlah usaha mikro kecil menengah meningkat sebesar 1 unit maka pertumbuhan ekonomi di provinsi Jawa Timur akan meningkat sebesar Rp 0,329. Berdasarkan pemaparan diatas dapat diketahui bahwa upaya yang dapat dilakukan oleh pemerintah provinsi Jawa Timur dalam meningkatkan pertumbuhan ekonomi adalah meningkatkan tingkat teknologi dan menambah jumlah pengusaha dan usaha yang ada di provinsi Jawa Timur.

\section{Pembahasan}

\section{Keterkaitan Antara Teknologi Terhadap Pertumbuhan Ekonomi di Provinsi Jawa Timur}

Salah satu upaya yang dapat dilakukan untuk terus meningkatkan pertumbuhan ekonomi di provinsi Jawa Timur adalah meningkatkan tingkat teknologi. Pada penelitian ini, tingkat teknologi didapatkan dari besarnya modal per tenaga kerja yang sedang bekerja atau yang dapat disebut berapa modal yang digunakan setiap tenaga kerja yang sedang bekerja di provinsi Jawa Timur. Berdasarkan kondisi tersebut, jika pemerintah provinsi Jawa Timur ingin meningkatkan teknologi yang dimiliki dan digunakan dalam perekonomian, maka tingkat modal yang digunakan per tenaga kerja harus semakin meningkat. Berikut gambaran pertumbuhan ekonomi dan tingkat teknologi di provinsi Jawa Timur

\section{Tabel 6 \\ Tingkat Teknologi dan Pertumbuhan Ekonomi}

\begin{tabular}{ccr}
\hline Tahun & Teknologi & \multicolumn{1}{c}{$\begin{array}{c}\text { Pertumbuhan } \\
\text { Ekonomi }\end{array}$} \\
\hline 2010 & 1.290 .545 & 342.281 .000 .000 .000 \\
2011 & 1.148 .079 & 366.983 .000 .000 .000 \\
2012 & 2.223 .988 & 393.663 .000 .000 .000 \\
2013 & 3.616 .700 & 419.428 .000 .000 .000 \\
2014 & 3.084 .603 & 1.262 .684 .500 .000 .000 \\
2015 & 3.634 .345 & 1.331 .395 .000 .000 .000 \\
2016 & 3.777 .392 & 1.405 .236 .100 .000 .000 \\
\hline
\end{tabular}

Sumber : Data BPS Provinsi Jawa Timur Tahun 20112017 diolah
Berdasarkan Tabel 6 dapat diketahui bahwa tingkat teknologi di provinsi Jawa Timur selama tahun 2010-2016 cenderung mengalami peningkatan meskipun pada tahun 2011 dan pada tahun 2014 mengalami penurunan jika dibandingkan dengan tahun sebelumnya. Berdasarkan Tabel 4 dapat diketahui bahwa adanya kecenderungan tren peningkatan teknologi di provinsi Jawa Timur juga diikuti dengan adanya peningkatan pertumbuhan ekonomi di provinsi Jawa Timur yang ditunjukkan dengan nilai produk domestic regional bruto (PDRB) provinsi Jawa Timur yang cenderung meningkat selama tujuh tahun yaitu dari tahun 2010-2016.

Jika pemerintah provinsi Jawa Timur menginginkan adanya peningkatan pertumbuhan ekonomi, maka pengembangan dan peningkatan teknologi yang digunakan harus tetap terjaga. Pengembangan dan peningkatan teknologi bukan hanya dilakukan pada kegiatan produksi semata, namun pada kegiatan non produksi ekonomi seperti pada kegiatan pendidikan atau ilmu pengetahuan yang harus dilaksanakan secara berkesinambungan. Hal ini dikarenakan semakin tinggi tingkat teknologi yang ada pada dunia pendidikan diharapkan dapat memunculkan inovasi-inovasi baru yang diciptakan oleh generasi muda sehingga keberlanjutan pertumbuhan ekonomi dapat berjalan dengan baik. Adanya inovasi dan peningkatan teknologi dalam dunia pendidikan juga diharapkan membahwa dampak pada peningkatan kualitas sumber daya manusia. Jika hal ini semua dapat dijalankan dan berkolaborasi dengan baik, maka peningkatan pertumbuhan ekonomi dapat dicapai. Wujud kegaitan yang dapat dilakukan dalam rangka meningkatkan kemajuan teknologi secara berkesinambungan melalui ilmu pengetahuan diantaranya terus meningkatkan program wajib sekolah dan peningkatan mutu pendidikan, memberikan dana pendidikan bagi warga yang tidak mampu serta pemerintah dapat membiayai sekolah serta peningkatan kesehatan (Wahyuni et al., 2013) 
Hasil penelitian ini juga sejalan dengan Lubis dan Kodatie (2013). Selain teknologi dapat membantu meningkatkan perekonomian dari sisi input, teknologi juga dapat meningkatkan perekonomian dengan adanya tingkat out put yang dihasilkan semakin meningkat dengan input yang digunakan tetap. Adanya penggunaan teknologi dalam perekonomian, mengakibatkan penggunaan input pada proses produksi semakin efisien sehingga out put yang dihasilkan oleh perekonomian provinsi Jawa Timur akan semakin meningkat (Kusumawardani, 2010).

Tingkat teknologi yang digunakan bukan hanya dapat meningkatkan out put saja dalam kegiatan ekonomi. Teknologi dapat menstimulus tenaga kerja untuk dapat menggunakan tenaga kerja lebih efisien, biaya produksi semakin murah sehingga produktivitas meningkat, dan yang paling penting dapat meningkatkan nilai kompetitif suatu negara pada perdagangan internasional (Calisakan, 2015). Kondisi ini dapat meningkatkan pertumbuhan ekonomi bukan hanya dilihat dari nilai tambah yang diberikan namun juga dapat dilihat dari meningkatnya nilai net ekspor yang dimilki suatu negara. Termasuk dalam teknologi bukan hanya teknologi maju saja, namun teknologi baru dikembangkan juga sangat penting dan memiliki efek pada kenaikan out put secara agreggat walaupun dalam nilai yang kecil (Crafts, 2010).

Peningkatan teknologi yang ada pada sutu negara juga memerlukan dorongan dan komitmen pemerintah dalam kegiatan sehari-hari. Selain itu menciptakan iklim menggunakan teknologi dalam setiap kegiatan ekonomi yang disertai dengan proses inovasi sehingga masyarakat menjadi terbiasa juga sangat mempengaruhi tingkat percepatan pertumbuhan ekonomi yang diharapkan mampu meningkatkan kualitas hidup masyarakat (Broughel dan Thiever, 2019; Nikoloski, 2016). Salah satu mem[ budayakan penggunaan teknologi dalam kegiatan ekonomi adalah menggunakan teknologi komunikasi internet dalam setiap kegiatan. Dengan adanya internet kegiatan ekonomi dapat berjalan lebih efisien dan cepat komunikasi antar pelaku kegiatan ekonomi sehingga dapat dikatakan bahwa teknologi informasi dan perekonomian merupakan suatu hal yang saling bergantung dan berhubungan satu sama lainnya (Hernandez et al., 2016; Qin dan Li, 2011)

Keterkaitan Antara Jumlah Usaha Mikro Kecil Menengah Terhadap Pertumbuhan Ekonomi di Provinsi Jawa Timur

Selain tingkat teknologi, besarnya pertumbuhan ekonomi juga dipengaruhi oleh jumlah usaha mikro kecil menengah yang ada di provinsi Jawa Timur. Berdasarkan persamaan pada Tabel 5 dapat diketahui bahwa jumlah UMKM memiliki nilai koefisien 0,32. Besarnya koefisien ini menandakan bahwa saat jumlah UMKM meningkat sebesar 1\% maka tingkat pertumbuhan ekonomi di provinsi Jawa Timur akan meningkat sebesar 0,32\%. Hubungan antara jumlah UMKM dengan pertumbuhan ekonomi provinsi Jawa Timur dapat dilihat pada Tabel 7 dibawah ini:

\section{Tabel 7}

Jumlah UMKM dan Pertumbuhan Ekonomi Provinsi Jawa Timur

\begin{tabular}{ccr}
\hline Tahun & $\begin{array}{c}\text { Jumlah } \\
\text { UMKM }\end{array}$ & \multicolumn{1}{c}{$\begin{array}{c}\text { Pertumbuhan } \\
\text { Ekonomi }\end{array}$} \\
\hline 2010 & 742.671 & 342.281 .000 .000 .000 \\
2011 & 783.955 & 366.983 .000 .000 .000 \\
2012 & 795.410 & 393.663 .000 .000 .000 \\
2013 & 803.453 & 419.428 .000 .000 .000 \\
2014 & 807.478 & 1.262 .684 .500 .000 .000 \\
2015 & 811.237 & 1.331 .395 .000 .000 .000 \\
2016 & 813.237 & 1.405 .236 .100 .000 .000 \\
\hline
\end{tabular}

Sumber: Data BPS Provinsi Jawa Timur Tahun 20112017 diolah

Berdasarkan Tabel 7 dapat diketahui bahwa jumlah UMKM cenderung mengalami peningkatan dari tahun 2010-2016 meskipun peningkatan jumlah UMKM tidak signifikan. Peningkatan jumlah UMKM ini juga diikuti dengan meningkatnya pertumbuhan ekonomi di provinsi Jawa Timur 
selama tahun 2010-2016. Peningkatan jumlah UMKM yang cukup besar terjadi pada tahun 2013 sebanyak 803.453 jumlah UMKM atau meningkat sebanyak 8.043 unit jika di- bandingkan dengan tahun 2012 yang sebesar 795.410 unit.

Bertambahnya jumlah UMKM memiliki dapak positif terhadap pertumbuhan ekonomi provinsi Jawa Timur dikarenakan kehadiran UMKM ini memiliki efek berganda bagi perekonomian. Semakin banyak UMKM yang ada maka pertama, semakin banyak lapangan kerja yang tersedia terutama lapangan kerja yang bersifat labor intensif. Hal ini dikarenakan sebagian besar UMKM yang ada di provinsi Jawa Timur merupakan labour insentif. Kondisi ini tentunya dapat membantu pemerintah dalam mengatasi masalah pengangguran disektor informal. Semakin banyak lapangan kerja yang diiringi dengan semakin banyaknya tenaga kerja maka semakin banyak out put barang dan jasa yang dihasilkan oleh perkonomian provinsi Jawa Timur. Meningkatnya out put yang dihasilkan merupakan salah satu indikasi adanya peningkatan pertumbuhan ekonomi.

Kedua, semakin besar jumlah UMKM maka perekonomian lokal akan semakin meningkat. Di Indonesia dan di provinsi Jawa Timur, jenis usaha yang dilakukan oleh UMKM sebagian besar berupa usaha yang memanfaatkan potensi lokal dimana UMKM tersebut berada baik dari sisi bahan baku maupun faktor produksi seperti tenaga kerja yang digunakan. Pasar dari produk UMKM sebagian besar juga wilayah sekitar dimana UMKM tersebut berada. Berdasarkan kondisi ini, jika semua wilayah kabupaten dan kota yang ada di provinsi Jawa Timur dapat memberdayakan ekonomi lokal melalui UMKM yang ada, maka secara simultan dan bersama-sama kemajuan ekonomi lokal dapat mendorong pertumbuhan ekonomi yang ada di provinsi Jawa Timur.

Hasil penelitian ini juga sesuai dengan hasil penelitian Chughtai (2014) di Pakistan jumlah UMKM memiliki hubungan yang positif dimana adanya inovasi membawa dampak yang signifikan pada pertumbuhan jumlah UMKM, pertumbuhan jumlah UMKM ini dapat menstimulus pertumbuhan ekonomi. Salah satu upaya yang dapat dilakukan oleh pemerintah provinsi Jawa Timur adalah memberikan pelatihan dan pendidikan yang dapat meningkatkan inovasi bagi pelaku UMKM. Jika pelakuUMKM dapat melakukan inovasi baik pada produk yang dihasilkan ataupun proses produksi yang dijalankan, akan berdampak pada peningkatan out put yang dihasilkan. Pada saat salah pelaku UMKM dianggap berhasil, maka akan memacu wirausahawan yang lain untuk mendirikan usaha yang serupa namun dengan produk yang sedikit berbeda. Jika hal ini terjadi maka semakin banyak lapangan kerja yang tersedia dan out put yang dihasilkan pada perekonomian domestik akan semakin meningkat sehingga pertumbuhan ekonomi di provinsi Jawa Timur dapat diwujudkan.

Taiwo et al. (2012) keberadaan UMKM di Nigeria memberikan dampak yang positif terhadap pertumbuhan ekonomi di Nigeria. Namun sayangnya pemerintah di Nigeria kurang memberikan perhatian yang penuh terhadap UMKM sehingga UMKM di Negria tidak dapat memainkan peranannya secara maksimal dalan pertumbuhan ekonomi. Oleh karena itu, pemerintah diharapkan memberikan suatu kebijakan yang dapat membantu UMKM untuk memainkan peranannya dalam perekonomian dintaranya melalui pemberian akses keuangan bagi kebutuhan modal serta akses akan informasi yang berkaitan dengan lingkungan bisnis. Berdasarkan penelitian yang dilakukan oleh Taiwo et al. (2012) pemerintah provinsi Jawa Timur dalam rangka mendukung berkembangnya UMKM dapat menyediakan akses informasi yang berkaitan dengan pemasaran produk dan informasi mengenai lingkungan bisnis. Banyak UMKM yang tidak dapat bertahan ditengah semakin kompetitifnya persaingan bisnis. Permasalahan utama yang dihadapi UMKM saat ini adalah pemasaran produk. Jika terdapat 
informasi yang tepat dan terpercaya mengenai saluran distribusi pemasaran dan situasi bisnis yang terkini akan menstimulus pelaku UMKM untuk mengembangkan usahanya dan menarik warga untuk memulai usaha barunya. Semakin meningkatnya peran UMKM dan semakin banyaknya jumlah UMKM dapat membantu menstimulus pertumbuhan ekonomi di wilayah provinsi Jawa Timur.

Hasil penelitian ini sejalan dengan penelitian yang dilakukan oleh Budi (2010) bahwa jumlah UMKM memiliki pengaruh terhadap pertumbuhan ekonomi. Berdasarkan hal tersebut dapat diketahui bahwa semakin makan banyak jumlah UMKM maka semakin banyak nilai produksi yang dihasilkan. Besarnya peningkatan produksi tentunya dipengaruhi oleh permintaan konsumen akan barang atau jasa yang dihasilkan. Kondisi ini tentunya berdampak pada peningkatan keuntungan yang didapatkan oleh produsen. Semakin besar pendapatan yang di dapatkan oleh pelaku UMKM maka semakin meningkat pula besarnya pertumbuhan ekonomi akibat peningkatan permintaan agregat sehingga out put yang dihasilkan juga meningkat. Berdasarkan Budi (2010) pemerintah provinsi Jawa Timur dalam rangka meningkatkan pertumbuhan ekonomi, dapat memberikan stimulus yang dapat membantu para pelaku UMKM untuk meningkatkan kapasitas produksinya. Peningkatan kapasitas UMKM dapat dilakukan pada beberapa aspek baik pada aspek produk maupun aspek pasca produksi. Pada aspek produksi peningkatan kapasitas produksi dapat dilakukan dengan cara adanya peningkatan pada teknologi yang digunakan dalam proses produksi serta adanya pengetahuan yang baru dalam proses tersebut. Pada aspek non produksi dapat dilakukan dengan memberikan informasi mengenai jaringan distribusi dan pelayanan setelah barang atau jasa disampaikan dan digunakan oleh konsumen. Pelayanan setelah sampai kepada konsumen, dapat memberikan informasi kepada produsen mengenai apa yang harus diperbaiki dan ditingkatkan atas out put yang dihasilkan.

Tahir et al. (2018) hadirnya usaha mikro kecil menengah bukan hanya dapat mempercepat pertumbuhan ekonomi, membuka lapangan pekerjaan dan adanya pendapatan namun juga pertumbuhan UMKM ini bertransformasi secara integral dengan transformasi perekonomian di Malaysia. Indetifikasi sektor mana yang memberikan kontribusi yang besar bagi kegitan ekonomi dapat memberikan informasi UMKM mana yang potensial untuk dikembangkan di masa depan. Sektor yang memberikan kontribusi kecil dapat dilakukan identifikasi upaya apa yang dapat dilakukan untuk mengembangkan UMKM yang berada di sektor tersebut. Jika hal ini dapat dilakukan maka peningkatan pertumbuhan ekonomi dan proses perubahan struktur ekonomi dapat berjalan lebih cepat. Proses transformasi struktur perekonomian yang berjalan dengan cepat dapat menstimulasi proses pembangunan ekonomi menjadi lebih cepat. Dapat dikatakan bahwa keberadaan UMKM memiliki hubungan yang cukup erat dengan pertumbuhan ekonomi dan percepatan pembangunan ekonomi (Karadag, 2016).

Keberadaan UMKM juga dapat memunculkan suatu inovasi baru atas out put yang dihasilkan sehingga dapat menstimulasi tingkat kompetitif antar pelaku UMKM, memunculkan sistem pengelolaa usaha serta dapat membangun sistem inovasi yang efektif bagi negara berkembang (Keskin at al., 2010). Oleh karena itu pemerintah perlu menerapkan suatu kebijakan yang dapat melindungi dan mempersiapkan UMKM untuk dapat bersaing dengan produk-produk asing serta memberikan infrastruktur yang dapat mendukung pengembangan UMKM (Bello at al, 2018). Hal ini dikarenakan pada UMKM bahan baku yang digunakan berasal dari lokal, tenaga kerja bersar dari lingkungan sekitar dan sebagian besar pemasaran juga di wilayah sekitar dimana UMKM berada. Jika UMKM dapat berkembang dengan baik maka pertumbuhan ekonomi akan tumbuh 
dengan baik karena disokong oleh kekuatan ekonomi dari lokal dan pembangunan ekonomi yang dilakukan dapat meningkat dan memberikan dampak peningkatan kesejahteraan bagi masyarakat.

\section{SIMPULAN}

Pertumbuhan ekonomi merupakan salah satu indikator yang penting bagi pembangunan ekonomi di provinsi Jawa Timur. Berdasarkan hasil penelitian didapatkan bahwa besarnya tingkat teknologi yang digunakan dan jumlah usaha mikro kecil menengah (UMKM) memiliki pengaruh yang positif terhadap pertumbuhan ekonomi di provinsi Jawa Timur. Upaya yang dapat dilakukan oleh pemerintah provinsi Jawa Timur untuk meningkatkan pertumbuhan ekonomi adalah memberikan suatu kondisi sosial dan ekonomi yang dapat menstimulus warga untuk membuka usaha mikro kecil menengah. Selain itu upaya peningkatan pertumbuhan ekonomi juga dapat dilakukan dengan cara meningkatkan kualitas sumber daya manusia serta menyediakan kondisi perekonomian dan sosial masyarakat yang sangat kondusif sehingga dapat menarik investor untuk berinvestasi di provinsi Jawa Timur. Pada penelitian selanjutnya hendaknya dilakukan identifikasi pengaruh teknologi dan jumlah usaha mikro kecil menengah pada masing-masing kabupaten atau kota sehingga analisis dalam pengambilan kebijakan yang dilakukan dapat dengan lebih tepat.

\section{DAFTAR PUSTAKA}

Badan Pusat Statistik. 2011. Provinsi Jawa Timur dalam Angka 2011. Badan Pusat Statistik Provinsi Jawa Timur. Surabaya. 2012. Provinsi Jawa Timur dalam Angka 2012. Badan Pusat Statistik Provinsi Jawa Timur. Surabaya. . 2013. Provinsi Jawa Timur dalam Angka 2013. Badan Pusat Statistik Provinsi Jawa Timur. Surabaya. 2014. Provinsi Jawa Timur dalam Angka 2014. Badan Pusat Statistik Provinsi Jawa Timur. Surabaya.
2015. Provinsi Jawa Timur dalam Angka 2015. Badan Pusat Statistik Provinsi Jawa Timur. Surabaya. . 2016. Provinsi Jawa Timur dalam Angka 2016. Badan Pusat Statistik Provinsi Jawa Timur. Surabaya. . 2017. Provinsi Jawa Timur dalam Angka 2017. Badan Pusat Statistik Provinsi Jawa Timur. Surabaya.

Bello, A, A. Jibir, dan I. Ahmed. 2018. Impact of Small Medium Scake Enterprises on Economic Growth: Evidence From Nigeria. Global Journal of Economic and Business 4(2): 236-244.

Broughel, J, dan A. Thiever. 2019. Technological Innovation and Economic Growth: A Brief Report on The Evidence. Mercatus Reseaarch: 1-29.

Budi, A. P. 2010. Analisis Pengaruh Nilai Produksi, Nilai Investasi dan Jumlah UMKM terhadap Produk Domestik Regional Bruto (PDRB) Provinsi Jawa Tengah 1983-2008: 71-86. https://digilib.uns.ac.id/dokumen/detail/129 08/Analisis-pengaruh-nilai-produksi-nilaiinvestasi-dan-jumlah-UMKM-terhadapProduk-Domestik-Regional-Bruto-PDRBprovinsi-Jawa-Tengah-Tahun-1983-2008. Diakses tanggal 3 November 2019.

Cakiskan, H. K. 2015. Technological Change and Economic Growth.Procedia Social and Behaviourial Scienes: 649-654.

Chughtai, M. W. 2014. Impact of Small and Medium Enterprise on Economic Growth: Evidence from Pakistan. Standard Research Journal of Business Management 2(2): 1-6.

Ghozali, I. 2009. Aplikasi Analisis Multivariate dengan Program SPSS. UNDIP. Semarang.

Crafts, N. 2010. The Contribution of New Technology to Economic Growth: Less From Economic History. Journal of Iberian and Latin American Economic History 28(3): 409-440.

Hapsari, P. P., A. Hakim, dan S. Soeaidy. 2014. Pengaruh Pertumbuhan Usaha Kecil Menengah (UKM) Terhadap Pertumbuhan Ekonomi Daerah (Studi di 
Pemerintah Kota Batu). Wacana, Jurnal Sosial Humaniora 7(2): 88-96.

Hernandez, K, B. Faith, P. D. Martin, B. Ramalingam. 2016. The Impact of Digital Technology on Economic Growth and Productivity and Its Implication For Employment and Equality: An Evidance Review. Evidence Report 207: 4- 39.

Karadag, H. 2016. The Role of SMEs and Entrepreneurship on Economic Growth in Emerging Economies within the Post Crisis Era: An Analysis From Turkey. Journal of Small and Entrepreneurship Development 4(1): 22-31.

Keskin, H, C. Senturk, O. Sungur, dan H. M. Kiris. 2010. The Importance of SMEs in Developing Economies.2nd International Symposium on Sustainable Development. Sarajevo 8-9 June.

Kuntara, T. 2016. Analisis Incremental Capital Output Ratio (ICOR) dan Pertumbuhan Ekonomi Provinsi di Pulau Jawa: 37-59

http://digilib.unila.ac.id/23883/Diakses tanggal 6 Mei 2019.

Kurniawan, D., T. Pamuji, dan T. R. Hayati. 2015. Penerapan Model Solow - Swan Untuk Memacu Pertumbuhan Ekonomi Kabupaten Demak. Media Ekonomi dan Manajemen 30(1): 68-75

Kusumawardani, R. 2010. Pengaruh Teknologi Terhadap Pertumbuhan Ekonomi Bandung Tahun 2008-2010. Skripsi. Program Sarjana IESP Universitas Syarif Hidayatullah. Jakarta.

Latumerissa, J. R. 2015. Perekonomian Indonesia dan Dinamika Ekonomi Global. Mitra Wacana Media. Jakarta.

Lubis, R. dan J. H. Kodatie. 2013. Pengaruh Teknologi Terhadap Produk Domestik Regional Bruto (PDRB) Provindi DKI Jakarta. Diponegoro Journal of Economic 2(1): 1-11.

Mankiw, G. A. 2006. Makroekonomi. Edisi Keenam. Erlangga. Jakarta.

Nikoloski, K. 2016. Technologi and Economic Development: Retrospective. Journal of Process Management 4(4): 45-50.
Qin, Z, dan Z. H. Li. 2011. Information Technology and Economic Growth-The Emperical Research Based on Spatial Econoic Model.International Conference on Information and Management Engginering: 302-312.

Rahman, S. 2016. Analisis Pengaruh Perkembangan Usaha Kecil dan Menengah Sektor Manufaktur Terhadap Pertumbuhan Ekonomi di Kota Makasar. Ad'ministrare 3(2): 71-82

Sukirno, S. 2012. Makro Ekonomi Modern. PT. Raja Grafindo Persada. Jakarta.

Sulaiman, M. T. 2013. Teori Pertumbuhan Ekonomi.

http://digilib.unila.ac.id/251/4/BAB\% 20II.p df. Diakses tanggal 3 November 2019.

Tahir, H. M, M. A. Rozak, dan F. Rentah. 2018. The Contribution of Small and Medium Enterprises (SME's) on Malaysian Economic Growth: A Sectoral Analysis. International Conference on Kansei Engginering and Emotion Research 739. Serawak 19-22 March.

Taiwo, M. A., A. Ayoeji, dan B. Yusuf. 2012. Small and Medium Ebterprise and Ecomic Growth in Nigeria. Acta Universitatis Danubiun 8(3): 45-53

Takahito, K. dan M. Kazuyuki. 2009. Infrormation Technology and Economic Growth: camparison Between Japan and Korea. RIETI Discussion Paper Series 7-E009: 1-27.

Todaro, M. P. 1997. Pembangunan Ekonomi di Dunia Ketiga. Edisi VI. Erlangga. Jakarta.

Undang-Undang Republik Indonesia Nomor 20 Tahun 2008 Tentang Usaha Mikro, Kecil dan Menengah. 4 Juli 2008. Lembaran Negara Republik Indonesia Tahun 2008 Nomor 93. Jakarta.

Wahyuni, S., A. Hamzah, dan S. Syahnur. 2013. Analisis Pengaruh Teknologi Terhadap Pertumbuhan Ekonomi Provinsi Aceh (AK Model). Jurnal Ilmu Ekonomi Pascasarjana Universitas Syiah Kuala 1(3): 71-79. 